\title{
HYPONATREMIA AND BRAIN INJURY
}

\author{
Absence of alterations of serum \\ brain natriuretic peptide and vasopressin
}

\author{
Karina Nascimento Costa', Helen Mayumi Nakamura², Leonardo Rodrigues da Cruz², \\ Lucas Sampaio Valente Fernandes de Miranda², Rubens Carneiro dos Santos-Neto², \\ Susyanne de Lavor Cosme ${ }^{2}$, Luiz Augusto Casulari3
}

\begin{abstract}
Objective: To study any possible relation between hyponatremia following brain injury and the presence of cerebral salt-wasting syndrome (CSWS) or the syndrome of inappropriate secretion of antidiuretic hormone (SIADH), and if vasopressin, brain natriuretic peptide (BNP) and aldosterone have a role in its mechanism. Method: Patients with brain injury admitted to the intensive care unit were included and had their BNP, aldosterone and vasopressin levels dosed on day 7. Results: Twenty six adult patients were included in the study. Nine $(34.6 \%)$ had hyponatremia and presented with a negative water balance and higher values of urinary sodium, serum potassium and diuresis than patients with normonatremia. The serum levels of BNP, aldosterone, and vasopressin were normal and no relation was observed between plasma sodium and BNP, aldosterone or vasopressin. Conclusion: The most likely cause of hyponatremia was CSWS and there was no correlation between BNP, aldosterone and vasopressin with serum sodium level.
\end{abstract}

KEY WORDS: hyponatremia, brain injury, natriuretic peptide, aldosterone, vasopressin.

\section{Hiponatremia e traumatismo cranioencefálico: ausência de alteração sanguínea do peptídeo natriurético cerebral e hormônio antidiurético}

Resumo - Objetivo: Estudar a possível relação entre a hiponatremia seguindo traumatismo cranioencefálico e a presença da síndrome cerebral perdedora de sal (SCPS) ou a síndrome da secreção inapropriada do hormônio antidiurético (SSIHAD), e se a vasopressina, peptídeo natriurético cerebral (BNP) e aldosterona têm um papel nesse mecanismo. Método: Foram incluídos pacientes com traumatismo cranioencefálico admitidos na unidade de terapia intensiva e foram dosados no sétimo dia seguindo o trauma, BNP, aldosterona e vasopressina. Resultados: Vinte e seis pacientes foram incluídos no estudo. Nove (34,6\%) tiveram hiponatremia e apresentaram um balanço hídrico mais negativo e altos valores de sódio urinário, potássio sérico e diurese quando comparados com o grupo que apresentou normonatremia. Os níveis séricos de BNP, aldosterona e vasopressina foram normais e não foi observada relação entre o sódio sérico e BNP, aldosterona e vasopressina. Conclusão: A causa mais provável da hiponatremia foi a SCPS e não houve correlação entre BNP, aldosterona e vasopressina com o nível sérico de sódio.

PALAVRAS-CHAVE: hiponatremia, traumatismo cranioencefálico, peptídeo natriurético, aldosterona, vasopressina.

\footnotetext{
Intensive Care Unit of the Hospital de Base do Distrito Federal, Brasilia DF - Brazil: ' Doctor, Intensive Care Unit of the Hospital de Base do Distrito Federal, Brasilia DF, Brazil; ' 2 Student, Escola Superior em Ciências da Saúde, Brasília DF, Brazil; ${ }^{3}$ Professor, Division of Endocrinology, University of Brasília, Brasília DF, Brazil.

This research received support from the Fundação de Apoio à Pesquisa do Distrito Federal, with resources from the Programa de Apoio a Jovens Pesquisadores - Programa Primeiros Projetos (Process number 193000192/2004).
}

Received 1 April 2009, received in final form 21 July 2009. Accepted 5 August 2009.

Dra. Karina Nascimento Costa - SQSW 100 / Bloco B / Apto.603 / Sudoeste - 70670-012 Brasilia DF - Brasil. E-mail: knc@terra.com.br 
Hyponatremia is common in patients with brain injury and it is associated with high morbidity and mortality rates'. Its physiopathology is not well described, but the cerebral salt-wasting syndrome (CSWS) ${ }^{2}$ and the syndrome of inappropriate secretion of antidiuretic hormone $(\mathrm{SIADH})^{3}$ have been considered causes of this disturbance. CSWS is the renal loss of sodium during intracranial illness, leading to hyponatremia, decrease of extracellular volume and dehydration ${ }^{4}$. Brain (BNP) and atrial (ANP) natriuretic peptides can be involved in the reduction of aldosterone and, thus, the renal loss of sodium ${ }^{5}$. SIADH is marked by the excess of vasopressin production, which causes water retention, accumulation of water in extracellular liquid and, as a consequence, dilution hyponatremia. We have previously published a detailed discussion of the differential diagnosis between the two syndromes'.

The mechanisms involved in its pathophysiology are not known ${ }^{6,7}$.

The objective of this work is to study the presence of SIADH or CSWS in hyponatremia following brain injury and if vasopressin, BNP and aldosterone are related to the lower sodium.

\section{METHOD}

This was an observational, analytical and prospective study involving patients with brain injury admitted to the Trauma Intensive Care Unit of the Hospital de Base do Distrito Federal in Brazil (HBDF), from December 2004 to July 2005.

The project was approved by the Research Ethics Committee of the State Health Department of the Federal District Government (Project number 171/2004). A legal representative of the patients signed the informed consent for their participation in the study.

Subjects with brain injuries who scored lower than 9 points at the Glasgow Coma Scale (GCS) were included ${ }^{8}$.

Patients were excluded when with cardiopathy (heart failure, congenital cardiopathy), acute or chronic renal failure, clinical signs of brain death upon admission, admission to the Trauma Intensive Care unit after more than one day of the trauma event, received glucocorticoid and diuretics during the study period, stayed in the Trauma Intensive Care Unit for less than 10 days and remained in the emergency room, because these patients did not have conditions of proper supervision, thus compromising the sampling of the research data.

\section{Delineation of the research}

The patients included in the study were evaluated according to age, sex, weight, cause of brain and associated injuries, the GCS upon admission, and the brain CT scan findings upon hospital admission.

For the ten days following the trauma, the serum sodium and potassium, hematocrit, and urinary sodium were assessed daily. Serum uric acid and osmolality were determined on days $1^{\text {st }}, 5^{\text {th }}, 7^{\text {th }}$, and $10^{\text {th }}$ following the trauma. Serum BNP, aldosterone, and vasopressin were assessed on the seventh day. That day was chosen because CSWS more frequently occurs at this period'. Urinary debit and water balance control was performed every 12 hours.

The hemodynamic monitoring included non-invasive measurement of blood pressure and cardiac frequency, using DIXTALDX 2710 monitor. The normal values for patients above 18 years old are: systolic blood pressure $<130 \mathrm{mmHg}$ and diastolic blood pressure $<85 \mathrm{mmHg}$; cardiac frequency between 60 and $100 \mathrm{bpm}$.

The daily amount of sodium supplied, in $\mathrm{mEq} /$ day, included the offer of sodium from both venous hydration and diet. Patients with hyponatremia were treated with increased daily infusion of intravenous sodium with physiological $0.9 \%$ saline or sodium chloride at $20 \%$. Volume replacement, whenever indicated, was done with either crystalloid (physiological solution at $0.9 \%$, Ringer or Ringer lactate) or colloid (albumin at $20 \%$ ).

Blood samples were collected between 7 and 9 am, centrifuged at $3000 \mathrm{rpm}$ for 10 minutes and the serum stored at $-20^{\circ} \mathrm{C}$ until assayed. For the dosages of BNP whole blood was drawn in a cooled syringe and in a frozen blood collecting tube with EDTA (ethylene-diamine-tetra-acetic acid) and kept on ice until submitted to centrifugation; the chemoluminescence method was used, with the kit - BNP DVIA Centaur ${ }^{\circledR}$ (Bayer Diagnostics Corporation, Tarrytown, NY, USA); to measure aldosterone whole blood was drawn without anticoagulant and radioimmunoassay method was used, with the kit - COAT-A-COAT ${ }^{\oplus}$ Aldosterone (DPC Diagnostic Products Corporation, Los Angeles, CA, USA); as to vasopressin measurements, whole blood was drawn on blood collecting tube containing EDTA and radioimmunoassay was applied with the $k i t$ - VASOPRESSIN ${ }^{125}$ I (INCSTAR Corporation - Stillwater, Minnesota, USA). Serum osmolality was assessed by Advanced Digimatic Osmometer model 3D2 (Advanced Instruments, Inc.).

\section{Statistical analysis}

Multiple linear regression model was used to study the relationship between plasma sodium and the variables BNP, aldosterone, vasopressin, diuresis, osmolality, sodium and urinary sodium levels on the seventh day of study.

The analysis of longitudinal data detailed the behavior of the variables urinary and plasma sodium, diuresis, and sodium level during the ten days of study in the two groups (hyponatremia and normonatremia). For that study, a model of mixed effects linear regression was used.

Pearson's coefficient of linear correlation was applied to verify the correlation between the variables BNP and aldosterone, plasma sodium and urinary sodium on the seventh day of study. Student's $t$ test was used to compare variables between normonatremia and hyponatremia groups. A level of significance of $p<0.05$ was considered. The results are presented as average \pm standard deviation for all studied variables. The software used was SAS version 9.1. 
Table 1. Demographic characteristics of the 26 patients who have suffered brain injury. Percentages are presented in parentheses (\%).

\section{Characteristics}

$\begin{array}{lc}\text { Age (years) } & 29.1 \pm 9 \\ \text { Male } & 22(84.6) \\ \text { Glasgow Coma Score } & 7 \pm 1.8 \\ \text { Glasgow Coma Score (3-5) } & 4(15.4) \\ \text { Glasgow Coma Score (6-9) } & 22(84.6) \\ \text { auses of brain injury } & \\ \text { Car crash } & 12(46.1) \\ \text { Being run over } & 6(23.1) \\ \text { Motorcycle accident } & 4(15.3) \\ \text { Fall from height } & 4(15.3)\end{array}$

\section{RESULTS}

During the study, 59 patients with severe brain injury were admitted to the intensive care unit, but 33 patients were excluded for the following reasons: admission to the unit with more than one day of trauma (16), death with less than 10 days of study (7), medical discharge from the unity in less than 10 days (3), brain death with less than 10 (5), acute renal failure (1) and previous cardiopathy (1). Twenty-six patients were then included in the study.

As presented on Table 1, most patients were young adults (18 to 54 years old), males and the most frequent causes of brain injury were car crash and being run over.

The most frequent injuries observed in the brain CT scan were brain swelling in 17 patients (65.3\%), intracranial bleeds in 13 (50\%), and brain contusion in 8 (30.7\%).

The associated injuries were bone fracture in $11 \mathrm{pa}-$ tients (42.3\%), pulmonary contusion in 3 (11.5\%), hemothorax and pneumothorax each in 2 subjects (7.7\%), liver injury, urethra injury, spinal trauma and nasal trauma, one case each (3.8\%). Three deaths occurred (11.5\%) and the causes were sepsis in two patients and brain death in one.

Six surgical procedures were performed (in parentheses the number of procedures): craniotomy for extradur- al hematoma draining (3), decompressive craniotomy (1), correction of open fracture (1), and amputation of right inferior limb (1).

The hemodynamic parameters in the seventh day following the trauma are presented on Table 2. Cardiac frequency and maximum systolic and diastolic blood pressure above normal limits in all cases. The patients in the hyponatremia group showed systolic blood pressure lower than the normonatremia group $(p<0.05)$. The hyponatremics, when compared with the normonatremia group, also showed higher serum potassium $(p<0.01)$, higher diuresis $(p=0.01)$ and negative water balance $(p<0.01)$ on days 6 and 7 following the trauma (Table 3).

\section{Laboratory variable analysis}

Hyponatremia (sodium $\leq 130 \mathrm{mEq} / \mathrm{L}$ ) was detected in 9 (34.6\%) patients, totaling 20 episodes. It occurred between the second and the tenth day of trauma, more frequently on the $6^{\text {th }}$ (four patients) and the $7^{\text {th }}$ (five patients). Plasma sodium values lower than $125 \mathrm{mEq} / \mathrm{L}$ were observed in three patients between days 5 and 9 following the trauma.

The values of serum uric acid and osmolality were normal, but hematocrit values on day 7 following the trauma were below normal (Table 3).

The values of BNP, aldosterone, vasopressin, plasma and urinary sodium, on the seventh day of study, were normal (Table 3).

Through multiple linear regression, a positive and significant relation was observed $(p=0.01)$ between the offer of sodium and plasma sodium, that is, for each one unit increase of sodium offered there was an addition of 0.011 units in the average plasma sodium. Serum osmolality also showed a positive and significant correlation with plasma sodium ( $p<0.01$ ), and each increase of a unit of osmolality led to an addition of 0.45 units in the average plasma sodium. No relation was observed between plasma sodium and BNP, aldosterone, vasopressin, and diuresis or between urinary sodium.

Table 2. Hemodynamic parameters in the seventh day following trauma in the 26 patients who have suffered brain injury.

\begin{tabular}{lccc}
\hline & Total & Hyponatremia & Normonatremia \\
Characteristics & $\mathrm{n}=26$ & $\mathrm{n}=9$ & $\mathrm{n}=17$ \\
\hline Maximum cardiac frequency $(\mathrm{bpm})$ & $119.8 \pm 17.8$ & $117 \pm 14.5$ & $121.2 \pm 19.6$ \\
Minimum cardiac frequency $(\mathrm{bpm})$ & $77.6 \pm 14.4$ & $75.3 \pm 13.5$ & $78.8 \pm 15.1$ \\
Maximum systolic blood pressure $(\mathrm{mmHg})$ & $154.5 \pm 18.7$ & $145 \pm 16.3$ & $159.3 \pm 18.5 \mathrm{a}$ \\
Minimum systolic blood pressure $(\mathrm{mmHg})$ & $112.3 \pm 15.5$ & $110.8 \pm 12.3$ & $113 \pm 17.2$ \\
Maximum diastolic blood pressure $(\mathrm{mmHg})$ & $95.9 \pm 18.3$ & $91 \pm 15.4$ & $98.5 \pm 19.5$ \\
Minimum diastolic blood pressure $(\mathrm{mmHg})$ & $61.4 \pm 11.8$ & $59.7 \pm 8.5$ & $62.2 \pm 13.5$ \\
\hline
\end{tabular}

Hyponatremia and normonatremia group: ${ }^{\mathrm{a}} \mathrm{p}<0.05$ 


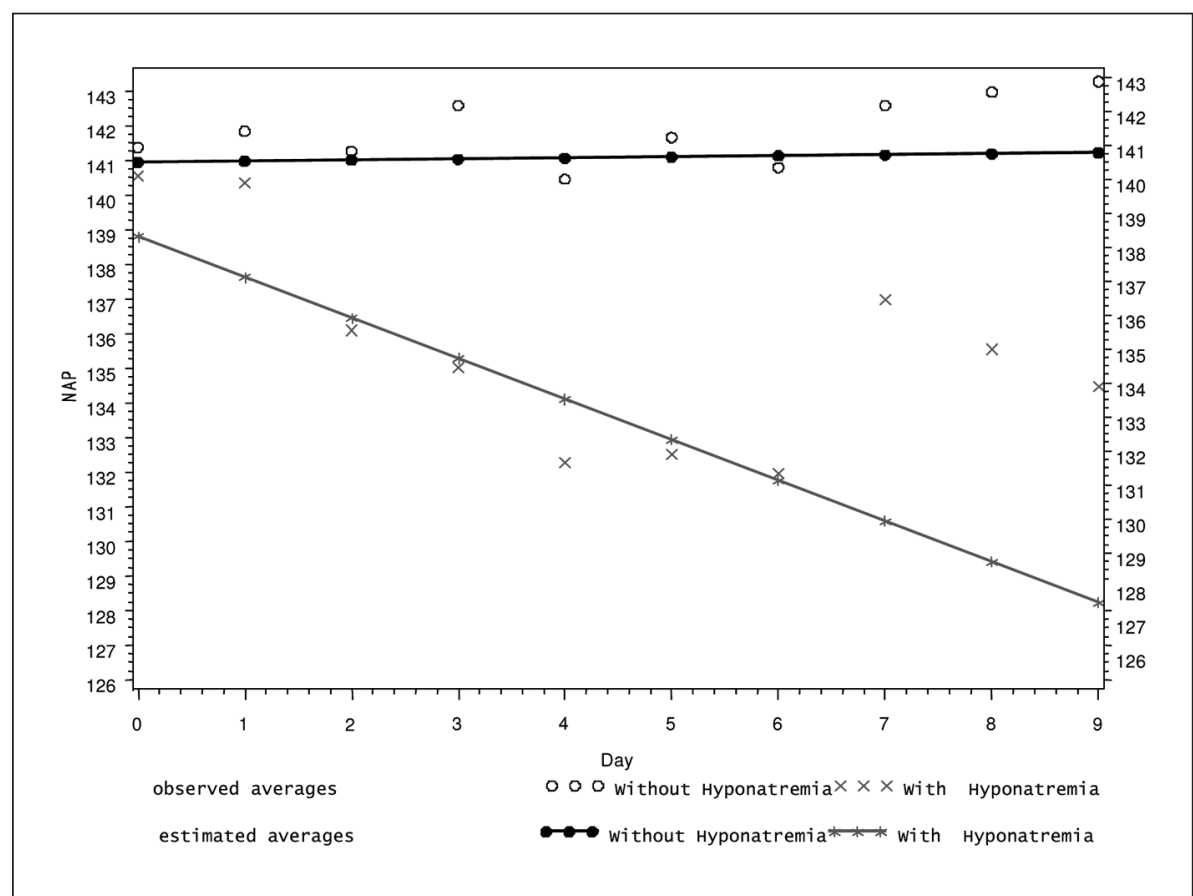

Fig 1. Plasma sodium during the 10 days of study in the group with hyponatremia $(n=9)$ and normonatremia $(n=17)$.

Table 3. Dosages of brain natriuretic peptide, aldosterone, vasopressin, serum potassium, and hematocrit ( $7^{\text {th }}$ day following trauma); uric acid, and osmolality $\left(1^{\text {st }}, 5^{\text {th }}, 7^{\text {th }}\right.$ and $10^{\text {th }}$ day following trauma); diuresis, offer of sodium, water and sodium balance, plasma and urinary sodium ( $6^{\text {th }}$ and $7^{\text {th }}$ day following trauma) in all 26 patients, the hyponatremia $(n=9)$ and normonatremia ( $\left.n=17\right)$ groups.

\begin{tabular}{|c|c|c|c|}
\hline Variable & $\begin{array}{l}\text { Total } \\
\mathrm{n}=26\end{array}$ & $\begin{array}{c}\text { Hyponatremia } \\
n=9\end{array}$ & $\begin{array}{c}\text { Normonatremia } \\
n=17\end{array}$ \\
\hline Brain natriuretic peptide $(\mathrm{pg} / \mathrm{mL})(\mathrm{VR}:<100 \mathrm{pg} / \mathrm{mL})$ & $17.7 \pm 16.1$ & $21 \pm 20.3$ & $16 \pm 13.8$ \\
\hline Aldosterone (ng/mL) (VR: 1-16 ng/100 mL) & $7.5 \pm 11.6$ & $8.6 \pm 10.9$ & $6.9 \pm 12.2$ \\
\hline Vasopressin (pg/mL) (VR: $0.4-2.4 \mathrm{pg} / \mathrm{ml} \mathrm{osm}<285 \mathrm{mOsm} / \mathrm{kg}$ ) & $1.9 \pm 0.7$ & $1.9 \pm 0.3$ & $1.8 \pm 0.9$ \\
\hline \multicolumn{4}{|l|}{ (VR: 2 a 12 pg/mml osm 285 mOsm/kg) } \\
\hline Potassium (mEq/L) (VR: $3.5-4.5 \mathrm{mEq} / \mathrm{L})$ & $4.1 \pm 0.4$ & $4.4 \pm 0.3$ & $3.9 \pm 0.2^{b}$ \\
\hline Plasma sodium (mEq/L) (VR: 136-145 mEq/L) & $137.2 \pm 6.7$ & $128.4 \pm 3.2$ & $141 \pm 4.6$ \\
\hline Urinary sodium (mEq/L) (VR: 100-200 mEq/L) & $139.6 \pm 69.6$ & $134.1 \pm 33$ & $129 \pm 65$ \\
\hline \multicolumn{4}{|c|}{ Uric acid (mg/dL) (VR: $<7 \mathrm{mg} / 100 \mathrm{dL}$ (male) and $<6 \mathrm{mg} / 100 \mathrm{dL}$ (female) } \\
\hline \multicolumn{4}{|c|}{ Days } \\
\hline 1 & $2.3 \pm 1.3$ & $1.9 \pm 1.5$ & $2.5 \pm 1.2$ \\
\hline 5 & $1.3 \pm 0.6$ & $1.2 \pm 0.7$ & $1.4 \pm 0.5$ \\
\hline 7 & $1.6 \pm 0.8$ & $1.4 \pm 1$ & $1.6 \pm 0.6$ \\
\hline 10 & $2.1 \pm 2.0$ & $2.7 \pm 3.2$ & $1.8 \pm 1$ \\
\hline \multicolumn{4}{|l|}{ Osmolality (mOsm/kg) (VR: 290-313 mOsmL) } \\
\hline \multicolumn{4}{|l|}{ Days } \\
\hline 1 & $303.4 \pm 12.5$ & $302 \pm 11$ & $304 \pm 13.4$ \\
\hline 5 & $298 \pm 8.5$ & $293.3 \pm 6.2$ & $301 \pm 8.6$ \\
\hline 7 & $295.6 \pm 8.3$ & $291.4 \pm 6.5$ & $298 \pm 8.5$ \\
\hline 10 & $303.3 \pm 15.8$ & $301 \pm 9.4$ & $305 \pm 19.1$ \\
\hline Hematocrit (VR: male $-47 \pm 7 \%$. female $-42 \pm 5 \%$ ) & $32.0 \pm 3.1$ & $32.1 \pm 1.7$ & $32 \pm 3.6$ \\
\hline Diuresis $(\mathrm{mL} / \mathrm{h})$ & $158.4 \pm 73.7$ & $215.4 \pm 73.1$ & $150.6 \pm 72^{a}$ \\
\hline Water balance (mL/24h) & $394.1 \pm 1937.1$ & $-1238 \pm 1493.3$ & $663.4 \pm 1961^{\mathrm{b}}$ \\
\hline Sodium balance (mEq/day) & $305.2 \pm 189.8$ & $242.2 \pm 89.2$ & $314.7 \pm 199$ \\
\hline Offer of sodium (mEq/day) & $444.7 \pm 171$ & $376.3 \pm 87.8$ & $444 \pm 187$ \\
\hline
\end{tabular}




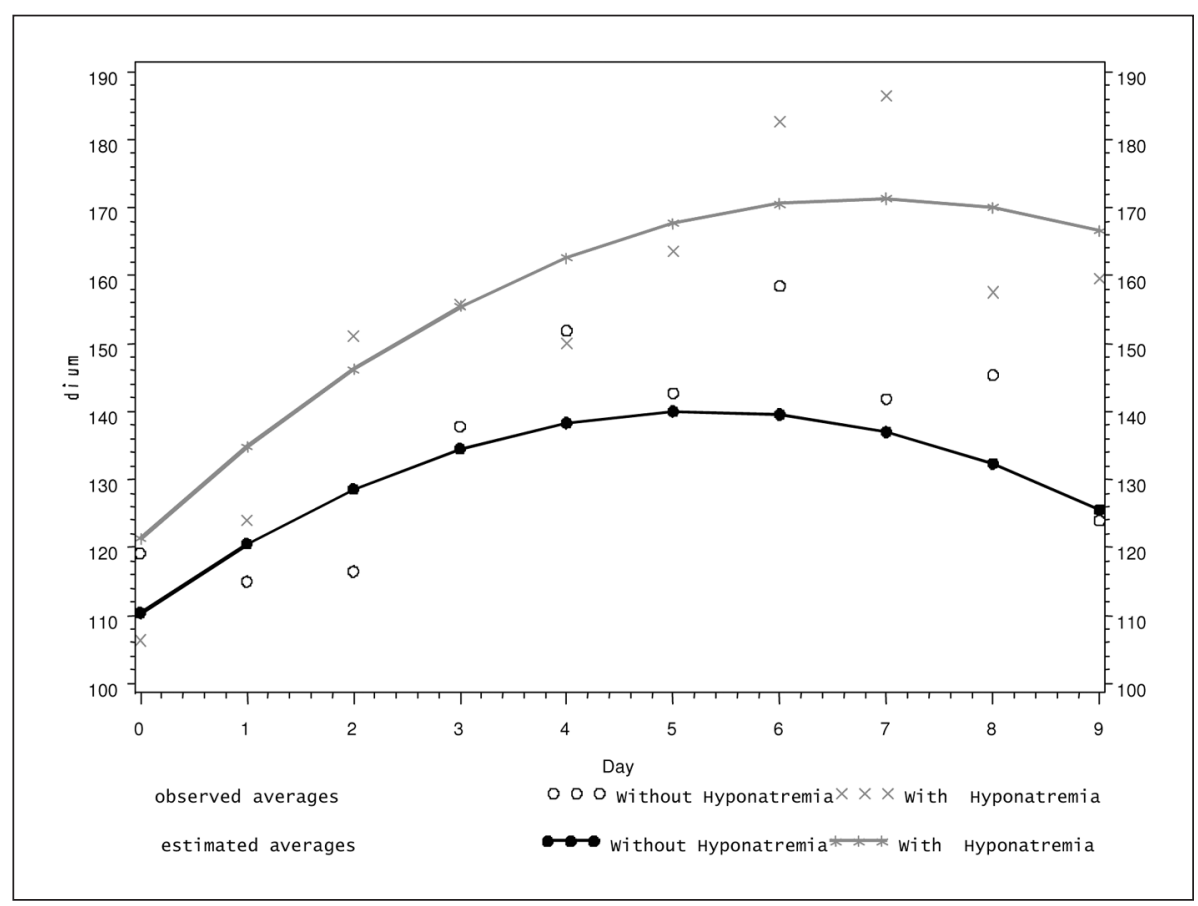

Fig 2. Diuresis during the 10 days of study in the group with hyponatremia (9) and normonatremia (17).

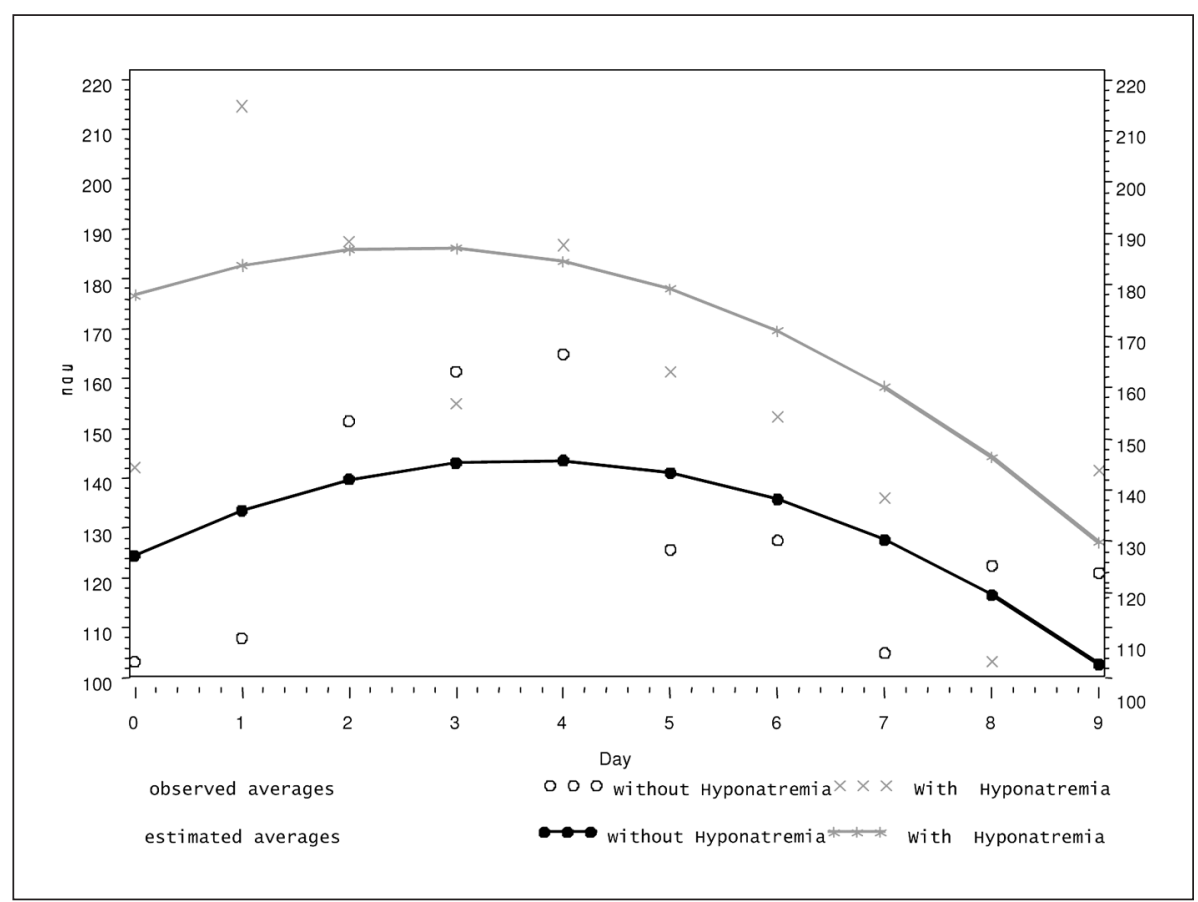

Fig 3. Urinary sodium during the 10 days of study in the group with hyponatremia (9) and normonatremia (17).

We did not observe a correlation between BNP and the following variables: aldosterone, plasma sodium and urinary sodium using Pearson's linear correlation.

We observed that, with regard to the behavior of plasma sodium throughout the 10 days of study, patients from the hyponatremia group showed a decreasing linear trend whereas the normonatremia group tended towards a constant behavior, as presented on Fig 1 .

Figure 2 shows that there was basically no difference between the two groups in the behavior of diuresis that is, the values tended to increase at first and to fall towards the end. However, average urinary volume in the hypona- 
tremia group was clearly superior to the average values of the normonatremia group.

As for urinary sodium (Fig 3), the hyponatremia group averaged $177.2 \mathrm{mEq} / \mathrm{L}$ in the first day, whereas the patients with normonatremia presented $127.7 \mathrm{mEq} / \mathrm{L}$, a statistically significant difference $(p<0.05)$. The behavior of the two groups practically did not differ, but the hyponatremia group showed higher values compared to the normonatremics.

The hyponatremic group showed a sodium average level slightly superior to the group with normonatremia throughout the 10 days, but that was not statistically significant ( $p=0.86$ ). It was also observed that the values of this variable remained constant throughout the whole period of evaluation at both groups.

\section{DISCUSSION}

This study demonstrated that patients with severe brain injury who showed hyponatremia had superior values of diuresis and natriuresis when compared to the normonatremia group, despite showing similar evolution of these variables throughout the 10 days of study. To our knowledge, this is the first time that the behavior of natriuresis and diuresis in patients who have suffered brain injury is detailed described.

Individuals that received an increased amount of sodium also presented this response, with renal excretion of sodium rising for 4 to 5 days before matching the of$\mathrm{fer}^{10}$. It is possible that the behavior of natriuresis was a consequence to the high amount of sodium supplied for the patients in this study, a measure to prevent hyperglycemia, which can itself worsen the prognosis of patients with brain injury"1.

Diuresis had similar evolution in the two groups, that is, it tended to grow initially and to fall towards the end. Natriuresis started with high values, remained high and later fell, especially in the hyponatremia group. This behavior was also described by other authors ${ }^{12}$. It can be explained because the reabsorption of water is linked to the reuptake of sodium. Thus, more reabsorption of sodium raises that of water in the proximal tubule, hence increasing urinary volume ${ }^{7}$.

We also observed hyponatremia (sodium $<130 \mathrm{mEq} / \mathrm{L}$ ), in $9(34.6 \%)$ patients. Hyponatremia following brain injury is frequent ${ }^{13}$ and in this study it occurred between the second and the tenth day of trauma, more frequently on the sixth and seventh days as observed by other authors ${ }^{14}$.

The nine hyponatremic patients had the CSWS as a probable etiology because of brain injury, natriuresis and hyponatremia ${ }^{7}$. They showed higher urinary sodium and volume, and a negative average water balance when hyponatremia occurred. The loss of water and natriuresis suggest a reduction on extracellular volume and, thus,
CSWS $^{15}$. However, these patients did not present clinical findings of dehydration, and that was not found by other authors either ${ }^{16}$, probably because of water balance control and replacement of losses. The sodium balance averaged positive in all patients of the group and can be explained by the higher offer of sodium received ${ }^{17}$.

Hyponatremia following severe brain injury has been associated with high levels of BNP and ANP ${ }^{18}$. The increase of these peptides must be a result of intracranial and subarachnoid hemorrhages and brain swelling ${ }^{18}$. However, despite the fact that the majority of our patients have showed these injuries, an increase of BNP on the seventh day after severe brain injury was not observed. It is possible that a single dosage during the 10 days did not reflect the previously described evolution of a gradual increase in the concentration of BNP found on victims of severe brain injury ${ }^{19}$.

Two other possibilities can justify the lack of increase of BNP. The first one would be that the offer of liquid and sodium was not enough to stimulate its secretion. Patients with subarachnoid hemorrhage who receive increased offer of liquid and sodium to prevent vasospasm ${ }^{18}$ showed greater release of natriuretic peptides. Although our patients showed positive water balance of $394.1 \pm 1,937.1 \mathrm{~mL} /$ day, they did not receive such a high daily offer of liquids.

The second possibility would be that our patients were submitted to mechanical ventilation whose level of positive end-expiratory pressure led to higher transpulmonary cardiac pressure, compromising atrial distension and, thereafter, the release of $A N P^{20}$. Such mechanism would be applied to BNP for the impairment of the cardiac ventricles distension ${ }^{21}$.

Besides the fact we did not observe an increase in the levels of BNP, it also did not correlate with the levels of sodium serum, and therefore did not correlate with CSWS. This data is in accordance with other authors who have also been unable to find an association between levels of $\mathrm{BNP}$ or ANP and the presence of CSWS ${ }^{22}$.

We observed that the urinary sodium concentration was high, an average of $137.2 \pm 6.7 \mathrm{mEq} / \mathrm{L}$, and this could lead to the generation of electrolyte-free water ${ }^{23}$. Thus the possible cause of hyponatremia presented in our patients could be the free water generated by the kidneys, caused by the excretion of hypertonic urine, the so-called desalination process. This water then would be incorporated into the intravascular volume, leading, thereafter, to hyponatremia. The antidiuretic hormone would be necessary for such incorporation.

All patients showed cardiac frequency, maximum systolic and diastolic blood pressure above normal limits (Table 2). The brain injury is associated with these alterations because it increases activity of the sympathetic nervous system, thus elevating noradrenaline and dopamine lev- 
$\mathrm{els}^{24}$. Dopamine acts directly impairing the absorption of $\mathrm{NaCl}$ and water in renal tubule, more precisely inhibiting the $\mathrm{Na}+-\mathrm{K}+-$ ATPase, with its effect mediated by the $\mathrm{D} 1$ receptor $^{25}$. The renal production of dopamine increases with a sodium-rich diet. Although our patients did not have the levels of dopamine measured, there is a possibility that they could have shown increased levels of dopamine caused by brain injury and by the increased amounts of sodium, leading to renal vasodilatation by the kidney and, as a consequence, natriuresis ${ }^{26}$.

Moreover, the patients received an increased infusion of sodium, which can also raise tensional levels and cardiac frequency. It is also possible that the observed increase in blood pressure in the present study could have contributed for the increase of natriuresis. In an experimental work, it was demonstrated that an increase in blood pressure leads to pressure natriuresis and diuresis, without, however, leading to changes in renal blood flow or the rate of glomerular filtration ${ }^{27}$. Natriuresis occurs due to decreased reabsorption of sodium in the proximal tubule, through the internalization by endocytosis of $\mathrm{Na}+-\mathrm{H}+$ contra transporters from apical membrane and from $\mathrm{Na}+-\mathrm{K}+-$ ATPase sodium pumps from basolateral membrane of the proximal tubule ${ }^{27}$. It was suggested that in CSWS this process of pressure natriuresis, together with BNP or other existing natriuretic agents, can lead to the increase of urinary sodium concentration ${ }^{22}$.

It is worth mentioning that the patients with hyponatremia showed lower values of systolic blood pressure when compared with the normonatremia group. This fact could have occurred due to the negative water balance, which could also explain the higher potassium levels observed in those cases.

Our patients showed severe brain injury that could have led to injuries of the pituitary with consequent reduction of growth hormone levels. This hormone activates the renin-aldosterone system in children with low stature $^{28}$, thus showing an anti-natriuretic function. The possible growth hormone deficiency could have lead to changes in the renin-aldosterone system, eventualy resulting in natriuresis, increased diuresis and hyponatremia.

The levels of uric acid were lower than $3 \mathrm{mg} / \mathrm{dL}$, a value that can be considered as hypouricemia ${ }^{10}$. A possible explanation for the reduction of uric acid reabsorption is the fact that this, along with sodium, is reabsorbed proximally in the nephron, and because the reabsorption of the latter is altered, uric acid would be more excreted ${ }^{15}$.

The average hematocrit was below normal because our patients are trauma victims ${ }^{29}$. The increased level of sodium and positive water balance can also have contributed for that finding?

Considering that the patients of this study showed normal average values of osmolality and that the values of vasopressin were normal, we can conclude that the patients did not show SIADH. The same result was observed by Moro et al.?

Plasma sodium showed a positive and significant relation with osmolality and offer of sodium. The positive correlation of these two variables is justified by the fact that sodium, along with glucose and urea, contributes for the osmolality value ${ }^{30}$.

In conclusion, hyponatremia was more frequent in the sixth and seventh day after trauma and it was most likely caused by CSWS. The group that presented hyponatremia had higher values of natriuresis and diuresis that could have been caused by pressure natriuresis and desalination. There was no correlation between brain natriuretic peptide, aldosterone and vasopressin with serum sodium level.

\section{REFERENCES}

1. Casulari LA, Costa KN, Albuquerque RC, et al. Differential diagnosis and treatment of hyponatremia following pituitary surgery. J Neurosurg Sci 2004;48:11-18.

2. Peters JP, Welt LG, Sims EAH, et al. A salt-wasting syndrome associated with cerebral disease. Trans Assoc Am Physicians 1950;63:57-64.

3. Schwartz WB, Bennett W, Curelop S. A syndrome of renal sodium loss and hyponatremia probably resulting from inappropriate secretion of antidiuretic hormone. Am J Med 1957;23:529-542.

4. Harrigan MH. Endocrine and metabolic dysfunction syndromes in the critically ill. Cerebral salt wasting syndrome. Crit Care Clin 2001;17: 125-138.

5. Sviri GE, Soustiel JF, Zaaroor M. Alteration in brain natriuretic peptide (BNP) plasma concentration following severe traumatic brain injury. Acta Neurochir (Wien) 2006;148:529-533.

6. Casulari LA, Borba AM, Lima BO, et al. Hiponatremia prolongada após traumatismo cerebral tratada com fludrocortisona. Brasília Med 2006;43:63-68

7. Moro N, Katayama Y, Igarashi T, et al. Hyponatremia in patients with traumatic brain injury: incidence, mechanism, and response to sodium supplementation or retention therapy with hydrocortisone. Surg Neurol 2007;68:387-393.

8. Jennet B, Bond M. Assessment of outcome after severe brain damage. A practical scale. Lancet 1975;1:480-484

9. Porto CC. Semiologia médica. 4. Ed. Rio de Janeiro, Guanabara Koogan, 2001.

10. Maesaka JK, Gupta S, Fishbane S. Cerebral salt wasting syndrome: Does it exist? Nephron 1999;82:100-109.

11. Vespa P, Boonyaputthikul R, McArthur DL, et al. Intensive insulin therapy reduces microdialysis glucose values without altering glucose utilization or improving the lactate/pyruvate ratio after traumatic brain injury. Crit Care Med 2006;34:850-856.

12. Mori T, Katayama Y, Kawamata T, et al. Improved efficiency of hypervolemic therapy with inhibition of natriuresis by fludrocortisone in patients with aneurysmal subarachnoid hemorrhage. J Neurosurg 1999;91:947-952.

13. Donati-Genet PCM, Dubuis JM, Girardin E, et al. Acute symptomatic hyponatremia and cerebral salt wasting after head injury: an important clinical entity. J Pediatr Surg 2001;36:1094-1097.

14. Virgerhoets F, Tribolet N. Hyponatremia hypo-osmolarity in neurosur-

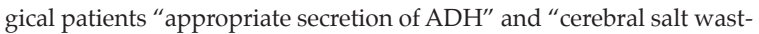
ing syndrome". Acta Neurochir (Wien) 1988;91:50-54

15. Palmer BF. Hyponatremia in patients with central nervous system disease: SIADH versus CSW. Trends Endocrinol Metab 2003;14:182-187.

16. Jimenez R, Casado-Flores J, Nieto $M$, et al. Cerebral salt wasting syn- 
drome in children with acute central nervous system injury. Pediatr Neurol 2006;35:261-263.

17. Wijdicks EFM, Ropper AH, Hunnicutt EJ, et al. Atrial natriuretic factor and salt wasting after aneurismal subarachnoid hemorrhage. Stroke 1991;22:1519-1524.

18. Fukui S, Katoh H, Tsuzuki N, et al. Focal brain edema and natriuretic peptides in patients with subarachnoid hemorrhage. J Clin Neurosci 2004;11:507-511.

19. Kirchhoff C, Stegmaier J, Bogner V, et al. Intratecal and systemic concentration of NT-proBNP in patients with severe traumatic brain injury. J Neurotrauma 2006;23:943-949.

20. Costa KN, Carvalho WB, Kopelman BI, et al. Dosagem do fator natriurético atrial em pacientes pediátricos submetidos à ventilação mecânica. Rev Ass Med Bras 2000;46:320-324.

21. Denus S, Pharand C, Williamson DR. Brain natriuretic peptide in the management of heart failure. Chest 2004;125:652-668.

22. Singh S, Bohn D, Carlotti AP, et al. Cerebral salt wasting: truths, fallacies, theories, and challenges. Crit Care Med 2002;30:2575-2579.

23. Steele A, Gowrishankar M, Abrahamson S, et al. Postoperative hypona- tremia despite near-isotonic saline infusion: A phenomenon of desalination. Ann Intern Med 1997;126:20-25.

24. Clifton GL, Ziegler MG, Grossman RG. Circulating catecholamines and sympathetic after head injury. Neurosurgery 1981;8:10-14.

25. Aperia A. Renal dopamine system and salt balance. Am J Kidney Dis 1998;31:xliii-xlv.

26. Israel A, Torres M, Cierco M, et al. Further evidence for a dopaminergic involvement in the renal action of centrally administered atrial natriuretic peptide in rats. Brain Res Bull 1991;27:739-742.

27. Zhang Y, Mircheff AK, Hensley CB, et al. Rapid redistribution and inhibition of renal sodium transporters during acute pressure natriuresis. Am J Physiol 1996;270:F1004-F1014.

28. Papadimitriou DT, Spiteri A, Pagnier A, et al. Mineralocorticoid deficiency in post-operative cerebral salt wasting. J Pediat Endocrinol Metab 2007;20:1145-1150.

29. Betjes MGH. Hyponatremia in acute brain disease: the cerebral salt wasting syndrome. Eur J Intern Med 2002;13:9-14.

30. Robertson GL. Antidiuretic hormone. Normal and disordered function. Endocrinol Metabol Clin North Am 2001;30:671-694. 